\title{
PERANAN GEMBALA SEBAGAI PEMIMPIN DALAM PERSPEKTIF I PETRUS 5:1-4 DAN RELEVANSINYA PADA MASA KINI
}

\author{
Yanda Kosta \\ sttjaffraymakassar@yahoo.co.id \\ Jermia Djadi \\ sttjaffraymakassar@yahoo.co.id
}

\begin{abstract}
ABSTRAK
Adapun tujuan dalam penulisan karya ilmiah ini adalah sebagai berikut: Pertama, untuk menemukan konsep peranan gembala sebagai pemimpin dalam I Petrus 5:1-4. Kedua, untuk merelevansikan konsep peranan gembala sebagai pemimpin dengan penggembalaan pada masa kini.

Adapun metode yang digunakan oleh penulis adalah Library Reseach atau penelitian perpustakaan, yaitu membaca buku-buku, menyelidiki kitab yang berkaitan dengan pokok bahasan karya ilmiah ini.

Berdasarkan semua uraian tentang peranan gembala sebagai pemimpin dalam perspektif I Petrus 5:1-4, maka dapat ditarik kesimpulan, konsep I Petrus 5:1-4 Tentang peranan gembala sebagai pemimpin bahwa seorang gembala harus mengerti peranannya sebagai pemimpin, yaitu: (1). Pemimpin yang memberi nasihat (I Petrus 5:1), seorang gembala sebagai pemimpin yang meberi nasihat harus mampu mengajarkan hal-hal yang baik dan menganjurkan sesuatu yang berguna bagi bawahannya atau orang-orang yang dipimpinnya, (2). Pemimpin yang bertanggung jawab (I Petrus 5:2a), seorang pemimpin sejati adalah orang yang penuh dengan rasa tanggung jawab, pemimpin yang mau memikul, menerima dan mengambil tanggung jawab dengan penuh kesadaran untuk tugas dan orang yang telah dipercayakan Tuhan kepadanya dan bukan orang yang menghindar dari tanggung jawab, (3). Pemimpin yang sukarela (I Petrus 5:2), sebagai pemimpin harus mampu menerima dan menlayani bawahannya dengan hati yang terbuka, senang dan bukan bekerja karena paksaan tetapi dengan kemauannya sendiri, (4). Pemimpin yang memberi teladan (I Petrus 5:3), sebagai pemimpin ada tuntutan sikap teladan dalam seluruh aspek kehidupannya baik kehidupan rohani, hubungan dengan orang lain, dalam pekerjaan, dan lewat sikap tegas.
\end{abstract}

Kata Kunci: Gembala Sebagai Pemimpin, dan Perspektif I Petrus 5:1-4. 


\section{PENDAHULUAN}

\section{Latar Belakang Masalah}

Konsep tentang gembala sebenarnya sudah ada sejak mulai penciptaan di Taman Edem setelah Allah menciptakan manusia pertama itu. Allah segera berperan dan bertanggung jawab terhadap apa yang Ia jadikan. Allah bukan hanya sekedar menciptakan manusia itu, lalu membiarkannya berjalan sendiri, melainkan mendelegasikan tugas kepada mereka dan mereka bertanggung jawab kepada Allah sebagai gembala. Dr. Peter Anggu mengatakan, "Allah sang Pencipta pada hakikatnya adalah gembala yaitu pelindung, pemelihara, atau penjaga umat-Nya. ${ }^{1}$

Gereja yang bertumbuh memerlukan seorang pelayan dalam arti gembala sebagai pemimpin yang berperan penting dalam pelayanan yang diberikan oleh Tuhan kepadanya. Seorang gembala menjadi gembala bukan karena memilih, tetapi karena ia terpanggil oleh Allah untuk menjadi gembala. $^{2}$ Dalam menunaikan tugasnya, seorang gembala haruslah orang yang sungguh-sungguh mengasihi Tuhan, yang setia dan bertanggung jawab, tidak mencari kepentingan diri sendiri atau puji-pujian yang sia-sia, tetapi menjadi teladan bagi semua orang Seorang gembala yang sungguhsungguh mengasihi Tuhan bukannya memilih jabatanya, melainkan dipilih untuk jabatanya. ${ }^{3}$

Dalam kitab Perjanjian Baru, Yesus bukan hanya digambarkan sebagai gembala yang baik, tetapi juga sebagai Gembala Yang Agung sesuai dengan pengakuan Rasul Petrus dalam nasihatnya. Dari kutipan di atas jelas bahwa penggembalaan bersumber dari Allah kepada mereka yang dipercayakan untuk melanjutkan tugas dan amanat tersebut. Dengan kata lain, penggembalaan yang benar diterima sebagai tugas dari Allah dan karena itu harus pula dipertanggungjawabkan kepada-Nya

Gagasan tentang peranan gembala sebagai pemimpin sudah jelas dalam Alkitab. Namun pada kenyataannya tidak sesuai dengan konsep yang ada. Artinya ada beberapa gembala yang melalaikan peranannya sebagai gembala dalam jemaat yang sudah dipercayakan oleh Allah kepadanya. Berdasarkan latar belakang masalah di atas, penulis terdorong untuk menulis karya ilmiah yang berjudul "PERANAN GEMBALA SEBAGAI PEMIMPIN DALAM PERSPEKTIF I PETRUS 5:1-4 DAN RELEVANSINYA PADA MASA KINI."

${ }^{1}$ Peter Anggu,. Etika Penggembalaan (Makassar: STT Jaffray. 2003),46

${ }^{2}$ Robert Cowls,. Gembala Sidang (Bandung: Kalam Hidup,n.d), 7

${ }^{3} \operatorname{Ibid} 7$ 


\section{Masalah Pokok}

Bertolak dari latar belakang di atas maka masalah pokok utama yang dikedepankan dalam penulisan karya ilmiah ini adalah bagaimanakah konsep peranan gembala sebagai pemimpin dalam menggembalakan jemaat berdasarkan I Petrus 5:1-4 dan bagaimanakah relevansinya bagi penggembalaan masa kini.

\section{Tujuan Penulisan} berikut:

Adapun tujuan dalam penulisan karya ilmiah ini adalah sebagai

Pertama, untuk menemukan konsep peranan gembala sebagai pemimpin dalam I Petrus 5:1-4.

Kedua, untuk merelevansikan konsep peranan gembala sebagai pemimpin dengan penggembalaan pada masa kini.

\section{Manfaat Penulisan} berikut:

Adapun manfaat dalam penulisan karya ilmiah ini adalah sebagai

Pertama, untuk dijadikan pedoman bagi pelayanan gembala sebagai pemimpin pada umumnya.

Kedua, sebagai bahan masukan bagi gembala yang sedang melaksanakan penggembalaan.

Ketiga, untuk memenuhi salah satu persyaratan akademik dalam mencapai gelar Sarjana Teologi di Sekolah Tinggi Filsafat Theologia Jaffray Makassar.

\section{Metode Penelitian}

Adapun metode yang digunakan oleh penulis adalah Library Reseach atau penelitian perpustakaan, yaitu membaca buku-buku, menyelidiki kitab yang berkaitan dengan pokok bahasan karya ilmiah ini.

\section{Batasan Penulisan}

Dalam penulisan ini, penulis memberikan batasan pada peranan gembala sebagai pemimpin hanya berdasarkan I Petrus 5:1-4, Adapun teoriteori tentang penggembalaan dan penjelasan yang berhubungan dengan gembala hanya sebagai bahan acuan, ide-ide bagi pelaksanaan peranan gembala dalam pengembangan jemaat. 


\section{KONSEP I PETRUS 5:1-4 \\ TENTANG PERANAN GEMBALA SEBAGAI PEMIMPIN}

Kepemimpinan Penggembalaan bermuara dari dasar pelayanan yang telah dilakukan oleh Yesus sendiri sebagai gembala yang sejati. Willyan Barcley mengatakan, "Yesus adalah gembala yang baik. Dia adalah gembala yang bersedia mengorbankan hidup-Nya untuk manusia yang tersesat dalam dosa." ${ }^{4}$ Yesus sebagai pemimpin, Dia juga yang memelihara umatNya, kemudian merawat mereka serta mencari yang telah tersesat. Seorang gembala harus melakukan tugas dan peranannya sebagai pemimpin, dalam hal ini tugas dan tanggung jawab harus dipahami dengan benar dalam suatu batasan peranan sebagai seorang gembala.

Gembala sebagai pemimpin. Salah satu peran dan tanggung jawab yang sangat menentukan pertumbuhan gereja adalah pemimpin. Pemimpin dapat menyebabkan gereja bertumbuh, dan sebaliknya dapat juga menyebabkan gereja tidak bertumbuh. Hal ini dapat dipengaruhi oleh perannya selaku pemimpin di dalam gereja. Gembala sebagai pemimpin harus mengajar Firman Tuhan kepada jemaat, harus melatih setiap anggota jemaat untuk melakukan pelayanan-pelayanan holistik. Harus mampu menyaksikan kasih Kristus kepada setiap orang dan ini peran utama bagi seorang pemimpin. "Setiap orang yang telah ditebus dipanggil untuk menjadi saksi bagi Tuhannya, bukan saja dengan hidup saleh, tetapi juga dengan usaha, saya harus melayani dan bersaksi bagi Tuhan." 5 Ini memberikan gambaran

bahwa gembala sebagai pemimpin berperan untuk bersaksi, gembala sendiri harus melaksanakan tanggung jawab bagi semua orang. Peranan seorang gembala sebagai pemimpin merupakan suatu fenomena khusus yang menyangkut tiga hal: mengajar, melatih dan bersaksi.

\section{Pemimpin yang Memberi Nasihat (I Petrus 5:1)}

I Petrus 5:1 mengungkapkan bahwa dengan otoritas tersebut, Petrus ingin meneguhkan para penatua dalam jabatanya yang berat itu dalam menghadapi masa penganiayaan dan penderitaan. Petrus disebutkan sebagai "Teman Penatua" tidak terdapat di tempat lain dalam Perjanjian Baru, tetapi tidak asing bagi Petrus dalam hubungan ini, di mana ia mementingkan kerinduan kesatuan dengan orang-orang yang diajaknya. ${ }^{6}$ Ayat 2 menunjukkan bahwa yang dimaksudkan bukan orang tua pada umumnya, melainkan pejabat-pejabat, yang disebut "Presbyterci" atau

\footnotetext{
${ }^{4}$ Willyam Barcley, Pemahaman Alkitab Setiap Hari (Jakarta : BPK Gunung Mulia, 2000), 86

${ }^{5}$ Andrew Murray, Membina Iman (Bandung: Kalam Hidup,1995),127

${ }^{6}$ Tafsiran Alkitab Masa kini 3 Matius-Wahyu (Jakarta: Yayasan Komunikasih Bina Kasih/OMF,2003), 832
} 
penatua. Selaku "teman penatua," Petrus tidak lebih tinggi kedudukannya daripada penatua-penatua biasa, melainkan mereka setara atau sederajat. ${ }^{7}$ Rangkaian penderitaan-kemuliaan dalam I Petrus 4:13; 5:1 yang menitikberatkan kemuliaan bagi orang-orang yang ikut serta di dalam penderitan Yesus Kristus. Namun dalam I Petrus 5:1 tidak berbicara langsung mengenai persekutuan "Petrus" dengan penderitaan Kristus, melainkan peranannya sebagai saksi dari kesengsraan Kristus. "Aku menasihatkan para penatua di antara kamu, aku sebagai teman penatua dan saksi penderita Kristu, yang juga akan mendapat bagian dalam kemuliaan yang akan dinyatakan kelak." Petrus ingin menekankan supaya pelaksanaan yang setia dari jabatan penatua adalah sangat penting dalam masa-masa menghadapi tantangan, penganiayaan, hambatan, dan penderitaan jemaat.

Kata "menasihati" Yunani $\pi \alpha \rho \alpha l v \varepsilon \omega$ (paraineo) menurut Kamus Umum Bahasa Indonesi adalah memberi nasihat kepada, mengajurkan, sedangkan "Nasihat" adalah ajaran, pelajaran baik; anjuran. ${ }^{8}$ Berkaitan dengan hal di atas, maka gembala harus mampu memberikan nasihat kepada anggota jemaat untuk selalu waspada akan sagala tantangan yang akan dihadapinya, "Waspadalah dan letakkanlah pengharapanmu seluruhnya atas kasih karunia yang telah dianugrahkan kepadamu pada waktu penyataan Yesus Kristus," menganjurkan, dan memberikan pelajaran yang baik kepada orang yang dipimpinnya, berpegang kepada Firman Allah, dan harus dikendalihkan oleh Roh Kudus sehingga ia merasa bahwa ia adalah atasan, tetapi sama dengan anggota yang turut dalam kepemimpinan jemaat.

Jadi, seorang gembala sebagai pemimpin yang memberi nasihat harus mampu mengajarkan hal-hal yang baik dan menganjurkan sesuatu yang berguna bagi bawahannya atau orang-orang yang dipimpinnya.

\section{Pemimpin yang Bertanggung Jawab (I Petrus 5:2a)}

I Petrus 5:2 menggambarkan tugas seorang gembala dengan kiasan yang baik, di mana mereka dipercayakan untuk menggembalakan domba Allah yaitu memberi makan. Kata ini mengingatkan amanat Tuhan Yesus kepada Petrus dalam Yohanes 21:15-19. Ungkapan "yang ada padamu" adalah ungkapan istimewa dalam bahasa Yunani "dengan seluruh kemampuanmu, sekuat tenaga, dalam terjemahan TB ungkapan ini dimaksudkan kawanan domba yang menjadi tanggungan khusus setiap penatua. ${ }^{9}$ Mereka tidak memiliki kawanan domba yang tetap, tetapi Tuhan mempercayakan domba-domba-Nya bagi mereka, maka mereka harus

\footnotetext{
${ }^{7}$ Ulrich Beyer Tafsiran Surat 1 dan 2 Petrus dan Surat Yudas (Jakarta: BPK Gunung Mulia,1972), 127

${ }^{8}$ Kamus Besar Bahasa Indonesia.S.V. "Nasihat"

${ }^{9}$ Tafsiran Alkitab Masa kini 3 Matius-Wahyu (Jakarta: Yayasan Komunikasih Bina Kasih/OMF,2003), 833
} 
bertanggung jawab kepada pemilik domba-domba tersebut, untuk tidak meninggalkan domba-domba itu. ${ }^{10}$ Tentang tingkalakuh dan perbuatan, pekerjaan gembala-gembala terdiri dari sisi negatif dan sisi positif yaitu mereka harus dinasihati supaya mereka melakukan tanggung jawabnya tanpa paksaan atau karena kewajiban. Dalam bahasa Yunani $\alpha v \alpha \gamma \kappa \alpha \sigma \tau \omega \varsigma$ artinya kewjiban, menurut Kamus Besar Bahas Indonesia kata "Kewajiban" adalah sesuatu yang diwajibkan, sesuatu yang harus dilaksanakan, keharusan. "l Sedangkan "Tanggung jawab" adalah keadaan wajib menanggung segala sesuatunya, fungsi menerima pembebanan; sebagai akibat sikap pihak sendiri atau pihak orang lain. ${ }^{12}$

Jadi, bertanggung jawab berarti keadaan wajib menanggung segala sesuatu, kerelaan memikul atau menangung segala akibat. J. Oswald Sanders mengatakan, "Memikul tanggung jawab dan melakukannya dengan rela, merupakan ciri yang perlu bagi seorang pemimpin." ${ }^{\prime 3}$ Salah satu syarat untuk menjadi gembala yang baik dan berkualitas adalah memiliki sikap yang bertanggung jawab, sikap bertanggung jawab ini sangat penting bagi seorang pemimpin yang telah disiplin dan dipanggil oleh Allah untuk memimpin dan menjaga umat-Nya agar tetap bergerak ke arah yang benar dan mengajarkan hal yang benar. Tanpa sikap tanggung jawab ini, maka tidak ada yang akan berhasil. Engstrom dan Dayton menuliskan, "Tidak ada yang akan terjadi bila tidak ada yang merasa dirinya bertanggung jawab." 14

Sikap tanggung jawab dari seorang pemimpin terlihat dalam hubungan tindakannya dengan tegas yang diberikan kepadanya, kepada bawahan yang dipimpinnya, dan kesediaanya menghadapi segala macam akibat yang ada (kesulitan dan kritikan). Tanggung jawab seorang pemimpin terhadap bawahan, menurut Diane Tracy adalah: "Memberi pengertian yang jelas mengenai tanggung jawab pekerjaan atau tugas yang harus dikerjakan. ${ }^{15}$ Tentang sikap tanggung jawab ini, Leroy Eims menulis, "Ada beberapa faktor yang mempengaruhi motivasi dan semangat, dan salah satu faktor kunci adalah kepemimpinan yang bertanggung jawab. Pemimpin yang bertanggung jawab penuh atas tindakannya sendiri dan atas tindakan orang bawahannya (yang dipercayakan Allah kepadanya) akan dihormati bawahannya dan akan setia kepadanya."

${ }^{10}$ Ulrich Beyer Tafsiran Surat 1 dan 2 Petrus dan Surat Yudas (Jakarta: BPK Gunung Mulia,1972), 130

${ }^{11}$ Kamus Besar Bahasa Indonesia.S.V. "Nasihat"

${ }^{12}$ Ibid. S.V. "Gembala"

${ }^{13}$ J. Oswald Sanders, Kepemimpinan Rohani (Bandung: Kalam Hidup,1999), 129

${ }^{14}$ Engstrom Dayton, Seni Manajemen Bagi Kepemimpinan Kriste. (Bandung: Kalam Hidup,1998),56

${ }^{15}$ Diane Tracy, 10 Langkah Meraih Kekuasaan (Jakarta: Pustaka Tangga,1999),1

${ }^{16}$ Leroy Eims, 12 Ciri Kepemimpinan Yang Efektif (Bandung: Kalam Hidup,1999),14 
Seorang pemimpin perlu memiliki sikap bertanggung jawab dan membuktikan diri sebagai pemimpin yang bertanggung jawab. Yacob Tomatala menuliskan dua faktor penting dalam mewujudkan diri sebagai pemimpin yang bertanggung jawab, yaitu:

Pertama, Pemimpin yang bertanggung jawab adalah pemimpin yang memikul tanggung jawab dengan sadar. Di sini orang Kristen dengan penuh kesadaran memikul tanggung jawab atas tugas yang dipercayakan kepadanya. Kedua, Pemimpin yang bertanggung jawab adalah pemimpin yang mengambil tanggung jawab pemimpin, orang Kristen harus secara pasti dengan penuh kesadaran tanggung jawab kepemimpinan untuk seluruh tugas dan orang yang dipercayakan kepadanya. Di sini tidak menggunakan gaya mencuci tangan ala Pilatus, tetapi ia sepenuhnya mengambil tanggung jawab, ia bukan saja sadar bahwa kepadanya telah dipercayakan tanggung jawab, tetapi ia mengambilnya secara teratur dan menunjukkan sikap dalam kinerja yang aktif. ${ }^{17}$

Jadi, seorang pemimpin sejati adalah seorang yang penuh rasa tanggung jawab. Pemimpin yang bertanggung jawab adalah pemimpin yang memikul, menerima dan mengamabil tanggung jawab dengan penuh kesadaran untuk tugas dan orang yang telah dipercayakan Tuhan kepadanya dan bukan seorang yang menghindari tanggung jawab. Sikap tanggung jawab seorang pemimpin terlihat dari kesediaannya menerima segala resiko (akibat, tantangan, dan kesulitan) dari tugas yang telah dipercayakan kepadanya, dan melaksanakan tugas dengan penuh rasa tanggung jawab.

\section{Pemimpin yang Sukarela (I Petrus 5:2)}

Sesuai dengan kehendak Allah adalah kemungkinan untuk menerjemakan kata Yunani "Trov" (Theon). Kemungkinan lain untuk mengartikan kata tersebut adalah "seperti perbuatan Allah sendiri" mengingat akan tugas "Gembala jiwa" seperti yang dikatakan dalam pasal

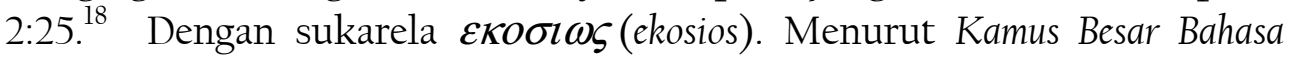
Indonesia "Sukarela" adalah dengan kemauan sendiri, dengan relah hati; atas kehendak sendiri, tidak karena diwajibkan. ${ }^{19}$

Jadi, seseorang yang bekerja dengan sukarela adalah orang yang bekerja dengan kemauannya sendiri bukan karena paksaan atau bukan karena suatu hal yang diwajibkan. Orang yang bekerja dengan sukarela disebut dengan sukarelawan. Karena seseorang bekerja atas kehendak diri

\footnotetext{
${ }^{17}$ Yakob Tomatala, Kepemimpinan yang Dinamis (Jakarta: Y.T. Leadership Foundation,1997), 50-51

${ }^{18}$ Tafsiran Alkitab Masa Kini 3 Matius-Wahyu (Jakarta: Yayasan Komunikasih Bina Kasih/OMF,2003), 833

${ }^{19}$ Kamus Besar Bahasa Indonesia S.V."Sukarela" 
sendiri, apa pun resikonya ia harus siap terima dengan lapang dada. Inilah yang dilakukan Yesus dalam menjalankan tugas yang diberikan Bapa kepada-Nya. Yesus menjalankan tugas-Nya dengan sukarela bukan dengan paksaan. Bahkan Yesus menyerahkan nyawa-Nya dengan sukarela.

J. Verkuyl memberikan penjelasan tentang bagian ini. Allah Bapa mengasihi Yesus, oleh karena kerelaan-Nya menyerahkan nyawa-Nya untuk keselamatan domba-domba-Nya, dan bukan karena terpaksa, tetapi karena kesukaan-Nya. Yesus tidak dipaksa mati, tetapi karena dengan sukarela menyerahkan nyawa-Nya. Ia berkuasa untuk menyerahkan nyawa-Nya dan berkuasa pula mengambilnya kembali, itulah rahasia kematiaan-Nya. Tugas itulah yang dilakukan-Nya. Sebab itu, Ia bebas terhadap kuasa dosa, iblis, dan maut. Yesus tidak mati sebagai hamba dosa, melainkan sebagai utusan Allah yang berbuat demikian dengan sukarela untuk membebaskan umat$\mathrm{Nya}^{20}$

Allah memberikan tugas yang paling mulia bagi para gembala sebagai pemimpin, jadi, setiap gembala sebagai pemimpin harus melaksanakan tugas pelayanannya denga sukarela bukan dengan paksaan. Sama seperti Yesus yang dengan relah menyerahkan nyawa-Nya sampai mati di kayu salib. Bukan karena paksaan sehingga apa pun resikonya harus diterima. Allah memerlukan orang yang mau melanyani Dia dengan sungguhsungguh, yang tanpa ragu-ragu mau menyerahkan segala sesuatu yang ada pada mereka, bahkan nyawanya sekalipun, demi kemuliaan Tuhan. Allah mengasihi orang-orang yang taat dan setia melakukan kehendak-Nya.

\section{Pemimpin yang Memberi Teladan (I Petrus 5:3)}

Memerintah dalam I Petrus 5:3 ini menyatakan sikap yang lazim bagi orang atasan dalam kekuasaan duniawi, dalam Markus 10:42. Di mana kata kerja yang sama dipakai, tetapi pemimpin Kristen, bukannya mempunyai wewenang tanpa batas dan memeras orang-orang yang dipercayakan kepadanya, melainkan wajib menjadi teladan kepada mereka, segala sesuatu yang dapat dilayankan dalam bidang pengajaran, pembinaan rohani. "Mereka yang telah dipercayakan kepadamu" (Yunani Kleroi) berarti "bagimu yang telah ditentukan." ${ }^{21}$ Rasul Petrus memberikan nasihat kepada para penatua untuk menjadi teladan. "Janganlah kamu berbuat seolah-olah mau memerintah atas mereka yang dipercayakan kepada kamu, tetapi hendaklah kamu menjadi teladan bagi kawanan domba itu" (I Petrus 5:3). Keteladanan merupakan suatu sikap yang sangat penting bagi kehidupan gembala sebagai pemimpin, karena lewat keteladanan hidup seorang gembala, menjadi salah satu faktor dalam pertumbuhan bagi iman

\footnotetext{
${ }^{20}$ Weslley Brill, Tafsiran Injil Yohanes (Bandung: Kalam Hidup, 1976), 138

${ }^{21}$ Tafsiran Alkitab Masa Kini 3 Matius-Wahyu (Jakarta: Yayasan Komunikasih Bina Kasih/OMF, 2003), 833
} 
jemaat, dalam hal ini gembala merupakan figur pemimpin yang mencerminkan keteladanan Allah kepada umat-Nya.

Menurut Kamus Besar Bahasa Indonesia, kata "teladan" adalah patut ditiru, baik untuk dicintohi. ${ }^{22}$ Penekanan yang terkandung dalam kata ini adalah pemimpin jemaat haruslah berusaha untuk layak dicontohi bagi semua orang, secara khusus kepada orang yang dipimpinnya.

Gembala sebagai pemimpin tidak dapat dipisahkan dari sikap keteladannya sebagai warna yang indah bagi jemaat dan bagi semua orang, baik dalam hal perkataan, tingkah laku, maupun dalam kasih, kesetiaan, dan kesucian. Berkaitan dengan hal di atas, seorang gembala harus memiliki perkataan yang jujur, berpegang kepada Firman Allah, dan harus dikendalihkan oleh Roh Kudus dan Firman Allah. Konsep Perjanjian Baru mengenai kepemimpinan, menuntut para penatua agar memandang diri sebagai hamba bagi yang lain...hendaklah menjadi teladan (I Petrus 5:3). ${ }^{23}$ Peter Wongso mengatakan, "Di dalam jemaat, pendeta memang seorang pemimpin, sikap dan perbuatan sering kali diteladani oleh jemaat mereka Oleh sebab itu, para pemimpin harus memelihara sikap dan perbuatan jemaatnya dengan sebaik-baiknya, yang terpenting adalah pemimpin harus mampu memberi teladan bagi orang lain. ${ }^{24}$ Allah sendiri menghendaki orang yang dipakai-Nya harus menjadi teladan, Allah ingin agar seorang pemimpin jemaat dapat menunjukkan sikap yang baik bagi jemaat sebagai mana Allah lebih dahulu menjadi teladan bagi umat-Nya.

Jadi, keteladanan dapat dicapai bilamana gembala sebagai pemimpin dapat melakukan kelima faktor yang dikatakan dalam (I Timotius 4:12) yaitu dalam perkataan, tingkalaku, kasih, kesetiaan, dan kesucian. Karena itu, seorang gembala haruslah memiliki sifat yang dapat diteladani seperti tersebut di atas.

Peranan seorang gembala sebagai pemimpin dituntut tampil sebagai teladan bagi jemaat, seperti Rasul Petrus menyampaikan nasihatnya kepada para penatua "janganlah kamu berbuat seolah-olah kamu mau memerintah atas mereka yang dipercayakan kepadamu, tetapi hendaklah kamu menjadi teladan bagi kawanan domba itu." Ralp M.Riggs Mengatakan,

Seseorang sama sekali tidak dapat mengajar dan memimpin orang lain kalau ia sendiri belum sanggup menjadi teladan. Tetapi biarlah orang itu menyadari bahwa kedudukannya sebagai seorang pemimpin meliputi kewajiban untuk lebih matang, lebih rohani, lebih setia, lebih bertekun di dalam doa, dan lebih saleh daripada anggotanya. Biarlah setiap

\footnotetext{
${ }^{22}$ Kamus Besar Bahasa Indonesia, S.V. "Teladan"

${ }^{23}$ Ronald W.Liegh, Melanyani Dengan Efektif (Jakarta: BPK Gunung Mulia, n.d), 222

${ }^{24}$ Peter Wongso, Theologia Penggembalaan (Malang: SAAT, 1983), 18
} 
gembala memperhatikan bahwa dia harus menjadi teladan yang baik bagi kawanan dombanya dalam semua hal. ${ }^{25}$

Sejalan dengan apa yang dimaksudkan Myron Rush, dalam bukunya menyatakan bahwa, salah satu peranan utama dari seorang pemimpin yang berhasil adalah menunjukkan teladan yang baik, kemudian melatih orang lain. ${ }^{26}$ Memperhatikan dengan saksama pernyataan-pernyataan di atas, maka gembala sebagai pemimpin adalah seorang yang harus menjadi teladan bagi orang-orang yang ditempatkan Allah di bawah pengawasannya. Ada kemungkinan di mana banyak orang tidak mengalami akan hal yang sedang gembala lakukan dan mereka akan menyangka bahwa mereka sedang memegahkan diri. Frederick K.C Price mengatakan, "Kita sebagai gembala harus menjadi teladan atau contoh kepada mereka yang kita gembalakan. Jika seorang pendeta menjadi teladan dalam segala sesuatu yang diperbuatnya kemungkinan besar akibatnya ialah jemaatnya akan menjadi seperti dirinya karena secara normal apa pun yang Anda jumpai dalam jemaat berasal dari mimbar." ${ }^{27}$ Keteladan seorang pemimpin dapat dilihat dalam beberapa hal seperti apa yang dikatakan oleh Sondang P. Siagian, "Seorang pemimpin harus mampu memproyeksikan kepribadian yang tercermin antara lain dalam bentuk kesetiaan kepada organisasi, kesetiaan kepada bawahan, dedikasi kepada tugas, disiplin dalam kerja, landasan moral dan etika yang digunakan, kejujuran, perhatian kepada kepentingan dan kebutuhan bawahan dan berbagai nilai-nilai hidup lainnya yang bersifat positif." 28

Dari uraian di atas jelas bahwa tanggung jawab dan peranan seorang gembala sebagai pemimpin dituntut adanya sikap teladan dalam seluruh aspek kehidupannya. Keteladan yang dituntut dari seorang gembala sebagai pemimpin dari sisi kehidupan, Yakob Tomatala mengatakan: Pertama, teladan hidup rohani. Pemimpin Kristen adalah pemimpin rohani yang harus membuktikan kualitas hidup. Ia harus memilki integritas rohani yang dalam dan kuat dan mewujudkan dengan setia dalam ketaatan kepada Allah dan Firman-Nya. Kedua, teladan hubungan dengan orang lain, hal ini diwujudkan secara konsisten memperhatikan orang, mempersatukan orang, membangkitkan semangat, berkomunikasi dengan baik. Ketiga, teladan kerja, pemimpin yang memiliki kecakapan tahu bagaimana memimpin, berpikir positif, sinargetis dan proaktif. Keempat, teladan dalam bersikap tegas, pemimpin yang bersikap tegas akan terbukti rajin atau giat, efektif

\footnotetext{
${ }^{25}$ Ralp M. Riggs Gembala Sidang Yang Berhasil (Malang: Yayasan penerbit Gandum mas,1996), 67 
dan efisiensi serta berorientasi kepada sasaran kerja. Pemimpin Kristen adalah pemimpin yang pragmatis serta produktif yang menghasilkan dalam kepemimpinannya. ${ }^{29}$

Berdasrkan pernyataan di atas, maka peranan gembala sebagai pemimpin merupakan pola hidup dan teladan yang perlu diperhatikan, diharapkan bahkan diri lebih dominan mempengaruhi serta mengubah pola pikir dan kehidupan orang lain, sehingga realitas kehidupan orang yang digembalakannya adalah cerminan dari hidup yang menggembalakannya. Keteladan hidup seorang gembala melibatkan juga seluruh anggota keluarganya terutama istri dan anak-anaknya.

\section{RELEVANSI PERANAN GEMBALA SEBAGAI PEMIMPIN BAGI PENGGEMBALAAN MASA KINI}

Setelah membahas peranan gembala sebagai pemimpin, kini pada bab IV penulis memberikan relevansi atau penerapan, yakni bamagaimana menerapkannya khususnya bagi pelayan-pelayan atau hamba-hamba Tuhan yang terjun lansung dalam pelayanan penggembalaan dan juga bagi para pembaca karya ilmiah ini . Relevansi yang penulis maksudkan akan dibahas di antaranya: konteks gembala masa kini, gembala sebagai pembimbing, sebagai gembala yang bertanggung jawab, menjaga dan melindungi jemaat, dalam mengajar, dalam berkhotbah, pemahaman Alkitab, sebagai pemberi teladan, teladan dalam kekudusan, teladan dalam penguasaan diri, teladan dalam keluarga.

\section{Konteks Gembala Masa Kini}

Pada prinsipnya konteks I Petrus tidak jauh beda dengan konteks masa kini. Namun fakta yang terjadi di lapangan bahwa di antara gembala atau penatua yang sungguh-sungguh melaksanakan tugasnya, masih ada yang bertindak sebagai gembala upahan atau mencari keuntungan sendir. Apa yang diajarkan tidak sesuai dengan praktika hidupnya atau kebenaran yang diketahui tidak dilakukan bahkan dilanggar, dan masih ada gembala yang kehidupannya tidak bisa diteladani. Banyak gembala yang bertindak sebagai gembala yang upahan bukan berati mereka tidak mengetahui kebenaran firman Tuhan, melainkan ada faktor-faktor yang menyebabkan sehingga mereka bertindak demikian, faktor utama adalah kerohanian gembala atau penatua yang belum baik, maka tidak mampu memimpin jemaatnya dengan baik.

\footnotetext{
29 Yakob Tomatala, Kepemimpinan yang Dinamis (Jakarta : YT. Leadership Foundation,1997), 56
} 
Dari penjelasan di atas penulis dapat menarik kesimpulan bahwa pada masa kini, banyak gembala yang sudah melaksanakan tanggung jawab pelayanannya dengan baik dan gembala seperti ini patut untuk diteladani. Namun masi ada juga gembala yang bertindak seperti gembala upahan. Mereka belum sepenuhnya hidup dalam firman Tuhan. Petrus menasihatkan para penatua untuk dapat menggembalakan kawanan domba Allah dengan penuh tanggung jawab, sukarela bukan dengan paksaan, melainkan menjadi teladan bagi kawanan domba yaitu jemaat. Bagaimanakah seharusnya menjadi seorang gembala.

\section{Sebagai Pembimbing}

Konseling atau bimbingan merupakan bagian yang penting dari pelayanan pastoral. Bimbingan memengang peranan yang sangat penting dalam penggembalaan jemaat. Setiap orang percaya mempunyai masalah, baik orang dewasa, pemuda maupun anak-anak; masalah pribadai, masalah keluarga, masalah pekerjaan dan sebagainya. Sebab itu, bimbingan sangat perlu dalam penggembalaan jemaat. Bimbingan harus dilakukan berdasarkan firman Tuhan. Bimbingan adalah satu karunia dari Tuhan. Bimbingan merupakan salah satu bentuk pastoral yang mempunyai kekuatan yang luar biasa bagi pertumbuhan jemaat. Sebab itu, setiap gembala perlu melaksanakan bimbingan untuk orang belum bertobat, dan anggota yang menghadapi pergumulan karena dosa, masalah rumah tangga, masalah pekerjaan dan sebagainya. ${ }^{30}$

Secara singkat dan sederhana dapat didefinisikan bahwa yang dimaksud dengan bimbingan adalah suatu percakapan dari hati ke hati antara seorang yang dibimbing dengan seorang yang dibimbing di mana pembimbing berusaha membimbing orang pembimbing untuk mengungkapkan segala permasalahan yang sedang dihadapinya secara terus terang atau terbuka untuk diselesaikan secara tuntas di hadapan Tuhan. ${ }^{31}$

Salah satu bidang pelayanan yang sangat penting dalam gereja adalah bimbingan khusus atau istilah yang dikenal dangan konseling kepada jemaat. Bimbingan khusus atau konseling merupakan suatu cara yang dilakukan untuk membimbing dan memberikan arahan secara spiritual kepada jemaat, di mana dapat dikatakan bahwa konseling adalah suatu proses memecahkan persoalan dalam kasih secara Alkitabiah, membina dan mendewasakan jemaat. Kamus Besar Bahasa Indonesia memberikan arti, "Konseling" adalah bimbingan oleh yang ahli kepada seseorang dengan menggunakan metode psikologis, pengarah, proses, pemberian bantuan oleh konselor kepada konsili sedemikian rupa sehingga pemahaman ,2005), 44

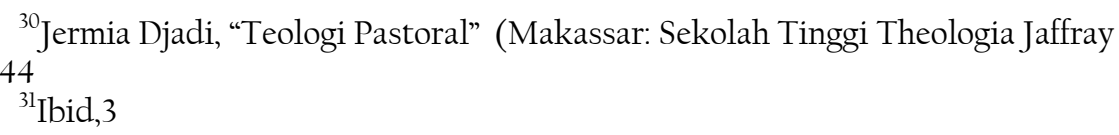

${ }^{30}$ Jermia Djadi, "Teologi Pastoral" (Makassar: Sekolah Tinggi Theologia Jaffray ${ }^{31} \mathrm{Ibid}, 3$ 
terhadap kemampuan diri sendiri meningkat dalam memecahkan berbagai masalah. $^{32}$

Konseling juga berarti memberi pertolongan kepada anggota jemaat dalam memecahkan masalah dan hal ini ditegaskan oleh Ruth F. Selan yang mangatakan, menolong konsili menghindari terjadinya kesulitan-kesulitan dalam kehidupannya, menolong untuk mengatasi masalah yang sedang dihadapinya, dan mengajar untuk mandiri supaya sanggup mengatasi problem pikiran dan kelakuan serta menolong konsili untuk mencapai kesejahteraan. ${ }^{33}$ Pada hakikatnya bahwa konseling menjadi suatu upaya dalam menolong jemaat untuk sampai kepada tingkat kedewasaan rohani dan seorang gembala berperan sebagai konselor bagi setiap jemaat. Seorang gembala adalah orang yang dipercayakan oleh Allah untuk membimbing dan menuntun domba-domba-Nya, sehingga mereka dapat mengalami damai sejahtera. Seorang konselor atau pembimbing harus peka terhadap orang-orang yang ia bimbing dan selalu siap untuk mendengar bimbingannya. Melihat definisi tersebut di atas, nyatalah bahwa peranan seorang gembala jemaat sebagai pembimbing sangat besar dalam bimbingan pastoral, keterbukaan orang yang dibimbing dan keberhasilan pembing dalam membimbing orang yang dibimbing untuk menyelsaikan permasalahan secara tuntas di hadapan Tuhan tergantung pada keterampilan gembala jemaat sebagai pembimbing. Di samping mengandalkan kuasa Roh Kudus, seorang pembimbing perlu memiliki pengetahuan psikologi karena yang dibimbing adalah jiwa manuisa. ${ }^{34}$

Keunikan dari bimbingan, menurut Yakub B. Susabda, paling sedikit ada empat unsur dasar pemikiran yang menentukan keunikan bimbingan pastoral, yaitu; (1) bimbingan pastoral adalah pelayanan hamba Tuhan yang dipercayakan oleh Allah. (2) bimbingan pastoral adalah pelayanan yang mutlak bergantung kepada kuasa Roh Kudus. (3) bimbingan pastoral adalah pelayanan yang didasarkan pada kebenara firman Tuhan. (4) bimbingan pastoral adalah bimbingan yang bersifat teologis dalam integritasnya dengan sumbangan ilmu pengetahuan lain, khususnya psikologi. ${ }^{35}$

Pelayanan bimbingan pastoral memang sangat unik dan mempunyai kekuatan yang luar biasa. Ini ternyata dari data yang dikumpulkan dari hasil penelitian di Amerika bahwa presentase dari orang-orang yang mencari bimbingan paling banyak datang kepada hamba Tuhan; (1) 42 54\% datang kepada hamba Tuhan ; (2) 29\% datang kepada dokter-dokter umum; (3) 18\% datang kepada dokter jiwa atau ahli ilmu jiwa; (4) 13\%

\footnotetext{
${ }^{32}$ Kamus Besar Bahasa Indonesia S.V. "Konseling"

${ }^{33}$ Ruth F. Selan, Bimbingan Praktis (Ujung Pandang: STT Jaffray, 1993), 2

${ }^{34}$ Jermia Djadi "Teologi Pastoral" (Makassar: Sekolah Tinggi Theologia Jaffray, 2005), 45

${ }^{35}$ Yakub B. Susabda, Pastoral Konseling. (Malang: Penerbit Gandum Mas, 1985), 49
} 
datang kepada pekerja-pekerja sosial; (5) 6\% datang kepada pengacara; (6) $3 \%$ datang kepada penasihat pernikahan; (7) $1 \%$ datang kepada guru, poloisi, hakim dan sebagainya. ${ }^{36}$

Berdasarkan data tersebut di atas, jelas bahwa pelayanan bimbingan pastoral mempunyai pengaruh yang paling besar. Oleh sebab itu, seorang gembala harus benar-benar mempersiapkan diri melengkapi diri,menjaga kepercayaan, dan kewibawaannya sebagai seorang gembala.

Pentingnya seorang pembimbing atau konselor di dalam penggembalaan adalah untuk menolong orang lain, untuk dapat mengenal dirinya, mengetahui kemampuan dan kekurangannya sehingga orang yang dibimbing dapat mengidentifaksikan apa yang menjadi kekurangan, dan apa yang menjadi kelebihan dalam hidupnya. Gembala sebagai pembimbing harus bisa menjaga kepercayaan bimbingannya, tidak membocorkan rahasia, menghormati dan menghargai bimbingan, menghindari untuk mengalihkan masalah bimbingannya kepada orang lain tanpa persetujuan yang dibimbingan. ${ }^{37}$

Bertumpu pada tujuan dan manfaat konseling yang menciptakan suatu pembinaan dalam meningkatkan kerohanian jemaat dalam gereja, maka dapat dikatakan bahwa konseling harus dilakukan oleh gembala atau hamba Tuhan sebagai suatu tugas dengan cara: pertama, seorang konselor harus bersandar sepenuhnya kepada Allah pada saat menolong atau membimbing anggota jemaat yang sedang bermasalah. Kedua, seorang konselor harus berdoa dan mendoakan kliennya (bimbingannya), sesuai dengan masalah yang sedang dihadapinya. Dengan demikian anggota jemaat dapat tertolong dari persoalan-persoalan, baik secara pribadi maupun di dalam keluarga, sehingga kerohanian jemaat dapat mengalami peningkatan.

Di dalam pelayanan pastoral bimbingan seorang gembala dapat menggunakan metode-metode agar tidak mengalami kesulitan di dalam menghadapi bimbingannya, metode-metode secara umum; (1) metode direktif. Dalam metode ini pembimbing tidak sebagai seorang ahli untuk menangani masalah-masalah orang yang dibimbing. Di dalam metode ini, peranan pembimbing lebih menentuka dan aktif, sedangkan orang yang dibimbing hanya sifatnya pasif menerima petunujuk-petunjuk dari pembimbing. Dengan kata lain orang yang dibimbing mempercayakan jalan keluar atas masalah-masalahnya kepada pertimbangan dan kemampuan pembimbing tanpa merasa perlu memberi pendapat. Jadi, metode direktif bepusat kepada pembimbing sehingga metode ini sering bersifat otoriter. (2) metode nondirektif (client centered), dalam metode ini interaksi lebih dititikberatkan kepada orang yang dibimbing sebagai pihak yang aktif. Pembimbing memberi kesempatan dan suasana bebas kepada orang yang

\footnotetext{
${ }^{36} \mathrm{Ibid}, 50$

${ }^{37}$ P.Tuhumury. "Pedoman Pimbinaan Pendidikan Kristen" (Makassar: STT Jaffray, 2003), 54-56
} 
dibimbing untuk mengutarakan pendapat dan perasaannya, tanpa takut untuk dikritik. Dasar dari metode ini adalah pada hakikatnya mempunyai potensi atau kemampuan dan tanggung jawab untuk memutuskan sendiri arah kehidupannya. Sebab itu, tugas pembimbing yang utama adalah memberi dorongan, rangsangan, semangat kepada orang yang dibimbing untuk memutuskan sendiri dan bagaimana menghadapi masalahmasalanya. (3) metode elektik. "elektik" adalah memilih dari berbagai sumber atau memilih berdasarkan selera. Dalam metode ini dimaksudkan agar pembimbing tidak terbatas pada satu metode saja, tetapi diharapkan mempunyai fleksibilitas dalam menggunakan berbagai macam metode bimbingan. $^{38}$

Jadi, dengan metode-metode tersbut di atas, seorang gembala yang dipercayakan oleh Tuhan mampu menolong bimbingannya untuk keluar dari masalah-masalah yang dihadapinya.

\section{Sebagai Gembala yang Bertanggung Jawab}

Salah satu tanggung jawab sebagai pemimpin adalah memperhatikan domba-domba gembalaannya, kata "memperhatikan" berasal dari kata "pemerhati" yang berarti orang yang memperhatikan, minat, mengamati. ${ }^{39}$ Setiap gembala sebagai pemimpin pada dasarnya dipercayakan oleh Allah dan orang lain. Oleh sebab itu, sebagai respon dari penghargaan yang telah diberikan, pemimpin harus memperhatikan orangorang yang dipimpinnya, sebab melalui perhatian, pemimpin akan mengenal apa sebenarnya yang menjadi kebutuhan dasar bagi orang yang dipimpinnya.

Yesus sebagai Gembala yang Agung, maka kedudukan kita adalah sebagai gembala bawahan-Nya (I Petrus 5:2-4; Kisah Para Rasul 20:28). Gembala Agung itu mempunyai banyak orang yang berfunsi sebagai bawahan-Nya. Dia telah menyuruh bawahan-Nya untuk memberi makan domba-domba-Nya dan senantiasa memperhatikan kebutuhan domba-Nya. Sikap ini haruslah menjadi prinsip bagi gembala yang menggembalakan jemaat, yaitu dengan sukarela mengorbankan waktu, tenaga, dan berusaha untuk bersungguh-sungguh menjadi teladan dalam memelihara anggota jemaat, bukan mementingkan diri sendiri (I Petrus 5:2-3). Perhatian dapat dinyatakan dengan hidup dekat dengan domba-domba, mereka akan mempercayakan diri mereka, karena mengetahui bahwa gembala jemaat memang orang yang memperhatikan keadaan pribadi mereka dan turut merasakan suka-duka bersama mereka. ${ }^{40}$ Gembala yang memperhatikan adalah gembala yang ingin tahu tentang keadaan jemaat. Karena ingin tahu

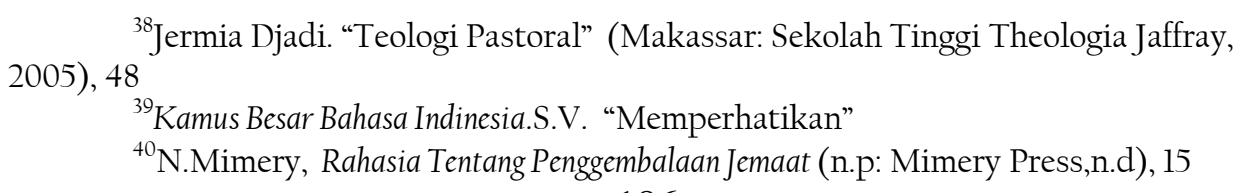


jemaat, maka gembala harus mengadakan penyelidikan berkali-kali terhadap jemaat, memperhatikan apa yang jemaat butuhkan, baik secara jasamani maupun secara rohani sehingga gembala dapat memberi jalan keluar yang pasti untuk jemaat.

Gembala harus memperhatikan anggota jemaat yang sedang berada dalam kesusahan dan bertindak untuk menolongnya dan memberi perhatian melalui firman Allah, mendoakan dan menguatkannya, anggota jemaat yang mengalami kemunduran iman atau yang sudah tidak aktif untuk menghadiri ibadah perlu diperhatikan oleh gembala. ${ }^{41}$ Gembala yang bertanggung jawab berarti gembala yang rela menanggung segala sesuatu, kerelaan memikul atau menanggung segala akibat. J. Oswald Sanders mengatakan, "Memikul tanggung jawab dan melakukannya dengan rela, merupakan ciri yang perlu bagi seorang pemimpin." ${ }^{42}$ Salah satu syarat untuk menjadi gembala yang baik dan berkualitas adalah memiliki sikap yang bertanggung jawab dan mengasihi. Kasih adalah landasan hidup dan pengabdian Yesus Kristus. Kasih dalam pengertian ini menunjuk kepada "Kemauan atau kerelaan yang menghendaki kebaikan tertinggi bagi sesama" yang ditandai oleh kemauan dan kerelaan untuk memberi diri berkorban bagi yang "dikasihi" (Yohanes 15:13). Kehidupan dan kualitas hidup berdasarkan kasih inilah yang dihidupi dan diamalkan oleh Yesus Kristus, yang merupakan landasan hidup dan kerja dari umat-Nya. Kasih dan mengasihi merupakan dasar dan dinamika kehidupan serta pengabdian Yesus Kristus yang dengan sendirinya harus diambil sebagai dasar dan praktika hidup serta pelayan kekristenan di mana pun. ${ }^{43}$

Seperti Tuhan Yesus yang menjadikan kasih/mengasihi sebagai landasan dan pengabdian-Nya ketika Ia di dunia. Seorang yang melayani tanpa kasih akan menjadikan pelayannya tidak berhasil, sebaliknya orang yang melayani dengan kasih akan membuat pelayanannya berhasil, bukan hanya di mata manusia, tetapi juga di mata Tuhan. Yesus sebagai Gembala yang Agung memberikan contoh kepada kita bagaimana Ia melayani dengan kasih, maka kita sebagai pengikutnya juga harus melayani dengan kasih. Setiap gembala sebagai pemimpin tidak bisa terlepas dari "kasih" dalam setiap pelayanannya, mengasihi anggota jemaat dapat diwujudkan dengan memberi makan kepada anggota jemaatnya melalui Firman Tuhan. Sebagai seorang gembala yang sedang memimpin yang benar-benar mengasihi domba-dombanya, ia senantiasa mencari dan menyediakan makan yang dibutuhkan oleh jemaatnya, yaitu Firman Allah. Sikap bertanggung jawab ini sangat penting bagi seorang pemimpin yang telah dipilih dan dipanggil oleh Allah untuk memipin dan menjaga umat-Nya agar tetap bergerak ke

\footnotetext{
${ }^{41}$ Ibid. 44

${ }^{42}$ J. Oswald Sanders, Kepemimpinan Rohani (Bandung: Kalam Hidup,1999), 129

${ }^{43}$ Yakob Tomatala, Menggembalakan Seperti Yesus Kristus (Jakarta: Yakob Tomata Leadership Foundation,2005), 5
} 
arah yang benar dan melakukan apa yang benar. Tanpa sikap tanggung jawab ini, maka tidak ada yang akan berhasil. Beberapa cara yang dapat dilakukan gembala di dalam hal memperhatikan domba-dombanya adalah: yang pertama, menguatkan anggota jemaat yang menderita atau sakit. Gembala yang benar-benar mengasihi jemaatnya akan selalu menguatkan mereka ketika meraka dalam kesusahan atau menderita, melalui nasihat Firman Tuhan, seperti Petrus menasihati jemaat yang ada di Pontus, Galatia, kapadokia, Asia kecil dan Batinia. (I Petrus 1:1) saat mereka mengalami penderitaan. Gembala yang mengasihi jemaatnya akan mengetahui setiap anggota jemaatnya yang sedang menderita atau sakit, baik secara jasmani maupun secara rohani. Yang kedua melindungi anggota jemaat dari serangan musuh. Gembala upahan tidak mengembalakan domba-dombanya dengan kasih, sebab ia hanya mengejar upah dan kebutuhan, sebab dengan cara itulah mereka dapat menambah penghasilannya. Sungguh memalukan, kalau ada orang Kristen yang purapura melayani Kristus dengan cara seperti itu, padahal memiliki keinginan sendiri. $^{44}$ Seorang pencuri hanya datang untuk merampok dan membinasakan, tetapi gembala yang mengasihi pasti akan melindungi domba-domba itu dari serangan musuh. Musuh domba-domba adalah serigala, harimau, beruang, pencuri dan perampok, sedangkan musuh bagi anggota jemaat adalah iblis yang digamabarkan sebagai singa yang mengaum-aum untuk mencari mangsanya (I Petrus 5:8).

\section{Menjaga dan Melindungi Jemaat}

Dalam injil Yohanes 21:16 TuhanYesus memberikan tugas dan tanggung jawab kepada Simon Petrus kata-Nya, "Gembalakanlah dombadomba-Ku." Hal yang sama pula diungkapkan Simon Petrus kepada para penatua dalam I Petrus 5:1-2. Kata "gembalakanlah" di sini berasal dari bahasa Yunani pomaine yang berarti "jagalah." Kata menjagai berarti "menunggu, mempertahankan keselamatan orang, mengawal, melindungi supaya jangan ditimpa bahaya, memelihara, mengawasi, merawat dan mencegah dari bahaya." ${ }^{45}$ Menggembalakan domba-domba Kristus berarti menjaga, melindungi, memelihara, merawat, mengawasi, dan mencegah domba-domba Kristus, yaitu angota jemaat dari bahaya. Para penatua ditugaskan untuk menggembalakan atau menjaga seluruh kawanan (jemaat Allah), karena ada bahaya yang mengancam, baik dari dalam maupun dari luar. Bahaya yang dari dalam, yaitu beberapa orang akan muncul dengan ajaran palsu dengan tujuan untuk memecah-belah jemaat. Sedangkan bahaya dari luar dilukiskan dengan serigala-serigala yang ganas yang akan masuk di tengah-tengah jemaat dan tidak akan menyayangkan

\footnotetext{
${ }^{44}$ Pendeta dan Tugas Pendidikan Dalam Jemaat (Pengarang Sebagai Entri Utama, STT Jaffray, n.d), 6

${ }^{45}$ Kamus Besar Bahasa Indonesia,S.V. "menjagai”
} 
kawanan itu (KisahPara Rasul 20:29). ${ }^{46}$ Untuk mengatasi bahaya yang mengancam anggota jemaat, baik dari dalam maupun dari luar, gembala jemaat harus berjaga-jaga dengan melakukan hal-hal sebagai berikut.

Pertama, mengadakan tindakan pencegahan, dengan jalan: (1) Gembala jemaat harus mengajarkan atau menanamkan doktrin yang benar kepada anggota jemaat; (2) gembala jemaat tidak boleh menerima sembarang pengkhotbah dari luar, sebelum diketahui latar belakang teologinya dengan jelas, jadi harus selektif; (3) gembala jemaat harus senantiasa mengingatkan anggota jemaat agar berhati-hati dan bersikap dewasa dalam mengikuti kegiatan-kegiatan di luar gereja sendiri, seperti Kebaktian Kebangunan Rohani (KKR), seminar-seminar, dan sebagainya. Anggota jemaat harus diajarkan untuk dapat membedahkan ajaran yang salah dan ajaran yang benar.

Kedua, mengadakan tindakan perawatan dan pengobatan. Namun, apabila terjadi hal-hal yang diluar dugaan, gembala harus segera mengadakan tindakan perawatan atau pengobatan dengan cara sebagai berikut. (1) Kalau ada anggota yang tersesat, harus segera dicari dan dibawa kembali ke jalan yang benar dalam roh yang lemah lembut dan belas kasihan (Galatia 6:1); (2) Kalau ada anggota jemaat yang jatuh ke dalam dosa harus segera diangkat dan dibimbing agar mereka jangan berbuat dosa lagi, Gembala jemaat bertanggung jawab atas jiwa mereka. ${ }^{47}$ (3) Kalau ada anggota jemaat yang susah dan berdukacita harus dihibur, yang sakit akan diberi pengobatan agar menjadi sembuh dengan beriman kepada Kristus.

Ketiga, mengadakan perkunjungan kepada setiap anggota jemaat. Gembala jemaat dalam menjalankan tugas dan tanggung jawabnya; menjaga, melindungi, merawat, memelihara, mengawasi anggota jemaat, dan mencegah dari bahaya, tidak cukup hanya mengajarkan doktrin yang benar melalui khotbah dari mimbar atau melalui kelompok pemahaman Alkitab. Lebih dari itu, gembala jemaat harus rajin mengunjungi anggota jemaat. $^{48}$

\section{Dalam Mengajar}

Konsep yang keliru dari sebagian pemimpin gereja yang mengartikan bahwa, mengajar adalah tanggung jawab guru dan bukan tugas gembala. Sebenarnya seorang gembala diharapkan cakap mengajar dan memiliki pengetahuan yang luas dan dalam. Pada prinsipnya bahwa pelayanan atau tugas yang dilakukan oleh seseorang pada umumnya ialah mengajar atau dengan kata lain kandungan dari pada tugas atau pelayanannya adalah

\footnotetext{
2005), 61

${ }^{46}$ Jermia Djadi,"Teologi Pastoral" (Makassar: Sekolah Tinggi Theologia Jaffray,

${ }^{47}$ N.Mimery, Rahasia Tentang Penggembalaan Jemaat (Mimery Perss,n.d), 38-45.

${ }^{48}$ Jermia Djadi. "Teologi Pastoral" (Makassar: Sekolah Tinggi Theologia Jaffray, 2005), 62-63
} 
pengajaran. Kamus Besar Bahasa Indonesia mengartikan kata "pengajaran" ialah segala sesuatu yang meliputi pekerjaan mengajar. ${ }^{49}$

Pengajaran merupakan suatu tindakan mengajar yang dilakukan kepada murid sehingga menjadi suatu proses interaksi antara guru dengan murid. Pengajaran bertujuan untuk menjelaskan kepada anggota jemaat apa yang mereka belum mengerti. Satu prinsip yang kita lihat dalam Matius 4:23-25 di mana Tuhan Yesus melakukan pengajaran Injil kepada orang banyak, Yesus sebagai pemimpin yang sejati tidak hanya memiliki wibawa dan otoritas, tetapi yang sangat penting ialah Yesus menjadi guru, yang mengajar sesuai dengan kosa kata, usia, sifat, dan kebutuhan orang-orang yang sedang Ia ajar. Salah satu rangkaian penting yang termasuk tanggung jawab seorang gembala adalah pengajaran. Pengajaran yang disampaikan kepada jemaat atau orang lain yang sedang diajar tidak hanya dengan satu pola dan bentuk, tetapi dalam berbagai pola yang tentunya disesuaikan dengan konteks orang-orang atau anggota jemaat.

Gereja dapat mengalami pertumbuhan yang sehat dan benar, karena salah satu faktor penting yang menunjang adalah pengajaran yang sehat dan benar. Anggota jemaat merupakan orang-orang yang dipercayakan Tuhan kepada pemimpin gereja. yaitu gembala untuk diajar dalam kebenaran Firman Tuhan. Sering kali pengajaran Firman Tuhan tidak efektif, disebabkan karena pengajaran tidak sesuai dengan konteks atau tidak memiliki kesiapan yang baik. Dua hal yang perlu diperhatikan oleh para hamba Tuhan secara khusus para gembala dalam menyampaikan kebenaran Firman Tuhan, yaitu: pertama, komunikasi, merupakan proses penyampaian makna dari satu orang kepada orang lain, dalam arti bahwa proses pengajaran dapat terjadi ketika ada komunikasi yang baik. Gembala sebagai guru dalam gereja harus memiliki suatu kemampuan dalam pengajaran, yang disampaikan melalui komunikasi yang baik. Dalam hal ini komunikasi dua arah "komunikasi" adalah pemindahan gagasan di antara orang-orang dalam bahasa yang dimengerti kedua pihak. Komunikasi seperti ini merupakan dasar dari kepemimpinan dan administrasi yang baik dalam gereja. ${ }^{50}$ Seorang gembala sebagai pemimpin harus mampu berkomunikasi dengan baik untuk menyampaikan pengajarannya dalam beberapa aspek, seperti berkhotbah, memimpin PA, dan pada saat menguatkan anggota jemaatnya. Berkomunikasi kepada jemaat dalam kehidupan sehari-hari haruslah bersifat motivasi sehingga dapat membangun kehidupan rohani jemaat. Kedua, tindakan, ini merupakan pola yang sangat penting bagi seorang gembala. Tindakan merupakan suatu sikap yang dilakukan seseorang untuk menyatakan perilakunya dalam menyatakan sesuatu. "tindakan" berarti suatu usaha atau perbuatan yang

\footnotetext{
${ }^{49}$ Kamus Besar Bahasa Indonesia,S.V. "Pengajaran"

${ }^{50}$ Kenneth O.Gandel, Membina Pemimpin Pendidikan Kristen (Malang: Gandum Mas, 2001), 363
} 
dilakukan terhadap hal yang perlu diatasi. ${ }^{51}$ Keberhasilan komuniksai seorang gembala ditentukan oleh tindakannya, dalam arti komunikasi dalam menyampaikan pengajaran bagi anggota jemaat akan membawa suatu perubahan kearah yang positif, jika konsistensi dari tindakan gembala direalisasikan dengan baik sesuai dengan komunikasi yang telah disampaikannya. Tindakan komunikasi yang dimaksud adalah keteladanan dan perilaku seperti yang dimaksudkan dalam I Petrus 5:3.

Dapat disimpulkan bahwa, gembala sebagai pemimpin gereja merupakan guru yang akan terus menerus mengajar atau memberi pengajaran kepada anggota jemaat, dengan tujuan jemaaat dapat mengalami pertumbuhan secara rohani dan mencari domba-domba yang tersesat. Tujuan dapat tercapai dengan baik, selain Roh Kudus yang berperan penting di dalamnya, juga harus disertai dengan pola pengajaran yang tepat dalam menyampaikan pengajaran kepada anggota jemaat, seperti dalam berkomunikasi yang baik dan tindakan yang tepat sehingga bukan saja jemaat dapat memahami tetapi juga jemaat dapat termotivasi untuk mampu melakukan pengajaran yang disampaikan oleh gembala.

\section{Dalam Berkhotbah}

Berkhotbah atau pelayanan mimbar merupakan salah satu cara yang diberikan oleh Allah untuk menyampaikan firman-Nya kepada umat Allah; namun perlu diingat bahwa berkhotbah merupakan cara yang amat penting. WarrenW.Wiersbe mengatakata, "Bagi Pendeta yang tahu membedahkan prioritas, maka berkhotbah menjadi tugas pelayannyanya yang nomor satu." 52 Menurut Philip Brooks. "Gembala haruslah seorang pengkhotbah yang baik agar dapat memelihara martabat pelayanannya. Pengkhotbah yang bukan gembala akan renggang hubungannya dengan jemaat. Gembala yang bukan seorang pengkhotbah adalah gembala yang picik." S3 Seorang gembala jemaat akan mengalami kesulitan dalam pelayanan apabila ia kurang yakin akan pentingnya hal berkhotbah atau rajin untuk berusaha menjadi pengkhotbah yang lebih mahir. Semua bentuk pastoral memang berfaedah dalam pelayanan gereja, namun tidak ada yang dapat menggantikan tempat khotbah berdasarkan firman Allah.

Menyadari pentingnya pelayanan berkhotbah, maka setiap gembala jemaaat harus menyiapkan khotbah dengan sebaik-baiknya dan menyampaikan khotbah yang benar-benar menguraikan firman Allah dengan cara yang baik pula. Tidak ada orang yang mengemban tugas lebih berat daripada orang-orang yang berdiri di mimbar atas nama Allah.

\footnotetext{
${ }^{51}$ Kamus Besar Bahasa Indonesia .S.V. "Tindakan”

${ }^{52}$ Warren W.Wiersbe, Prioritas Seorang Pendeta (Malang: Penerbit Gandum Mas,1982), 7

${ }^{53}$ Warren W.Wiersbe dan Howard F. Sugden, Memimpin Gereja Secara Mantap.(Bandung: LLB, 1994), 72
} 
Menyiapkan dan menyampaikan khotbah yang alkitabiah merupakan pekerjaan yang berat dan tanggung jawab dari seorang gembala jemaat. Adapun tanggung jawab gembala dalam pelayanan mimbar atau berkotbah adalah, (1) mempelajari firman Allah. Alkitab adalah bagaikan kekayaan yang tersembunyi dan gembala jemaat harus menggalinya setiap hari. Kemudian barulah mengajarkan ketetapan dan peraturan itu bagi jemaat. Gembala jemaat harus lebih dahulu menjadi murid yang paling rajin mempelajari firman Allah. Dalam hal ini gembala jemaat harus mampu untuk disiplin waktu dan bertekun dalam mempelajari firman Allah. (2) mempersiapkan berita untuk jemaat. Gembala tidak cukup hanya belajar firman Tuhan, ia harus juga mengenal jemaat. Ia harus dapat menyampaikan berita sesuai dengan kebutuhan jemaat. (3) memberitakan kebenaran dengan sungguh-sungguh. Biarlah jemaat melihat bahwa gembalanya selalu bersungguh-sungguh, baik di mimbar maupun di luar mimbar. (4) menyampaikan khotbah dengan kasih dan kuasa Roh Kudus. Gembala harus menyampaikan khotbah dengan kehangatan kasih dan semangat rohani dari kuasa Roh kudus. Oleh sebab itu, ia sendiri mempersiapkan dirinya ketika mempersiapkan khotbah. Seseorang tidak dapat memisahkan khotbah dari pengkhotbah, sebab pelayanan itu bukan terdiri dari apa yang dilakukan, tetapi terdiri atas sifat dan keadaannya. Keduanya harurs dipersiapkan. Jika seseorang memimta orang lain untuk menurutinya, maka pertama-tama ia harus menurut. Dan khotbah yang disampaikan dengan kehangatan kasih akan mendatangkan berkat bagi jemaat yang mendengarnya. (5) kesediaan untuk didatangi jemaat sesudah mereka menerima khotbah. Khotbah yang baik dapat dibuktikan dengan orangorang yang datang kepadanya untuk dilayani sebagai respons terhadap khotbah yang telah disampaikan kepada mereka. ${ }^{54}$

Jadi, seorang gembala yang mampu berkhotbah dengan baik adalah gembala yang tekun belajar firman Allah dan memiliki waktu untuk bergaul dengan jemaatnya agar dapat mengenal kebutuhan jemaatnya.

\section{Pemahaman Alkitab}

Selain dibimbing secara pribadi, jemaat juga perlu diajar kebenaran Firman Tuhan melalui penelaah Alkitab (PA), adapun tujuan (PA) adalah "supaya setiap peserta 1. Mengenal Tuhan Yesus dan menerima keselamatan-Nya (Roma 10:9), 2. Mengerti kehendak Tuhan dalam hidupnya (Roma 12:2), 3. Mendapat pendoman hidup (II Timotius 3:17), 4. Sanggup menyampaikan Firman Allah yang dipelajarinya kepada orang lain ( II Timotius 2:2), ${ }^{55}$ 5. Menjadikan kita seorang Kristen yang kuat, 6. Memberitahu kita bagaimana menyucikan diri dari dosa, 7. Memberi

\footnotetext{
${ }^{54}$ Jermia Djadi, "Teologi Pastoral” (Makassar: Sekolah Tinggi Theologia Jaffray, 2005), 33

${ }^{55}$ Ruth F Selan, Pembina Warga Jemaat (Bandung: Kalam Hidup,1994), 72
} 
sukacita, 8. Membimbing kita dalam melakukan keputusan-keputusan dalam hidup kita, membuat kita dapat menyatakan iman. Dan akhirnya mengalami pertumbuhan di dalam Tuhan. PA juga merupakan salah satu alat yang efektif untuk memenuhi Amanat Agung Kristus guna menjadikan bangsa murid-Nya. ${ }^{56}$ Pemahaman Alkitab merupakan salah satu pelayanan yang sangat penting untuk dilaksaskan oleh seorang gembala sebagai pemimpin dalam meningkatkan kualitas kerohaniaan jemaat. Yang dimaksudkan pemahaman Alkitab dalam kelompok kecil adalah suatu unsur yang digunakan di mana anggota jemaat berkumpul dalam kelompok kecil untuk menyelidiki Alkitab secara kelompok. Jermia Djadi dalam "diktat penggembalaan II" mengatakan, "Anggota jemaat harus dibagi dalam kelompok-kelompok yang kecil untuk menyelidiki Firman Tuhan. Melelui pemahaman Alkitab dalam kelompok kecil setiap anggota jemaat dapat diajar untuk menemukan sendiri kebenaran Firman Tuhan, di dalam PA itu setiap anggota jemaat itu diberi kesempatan untuk menanyakan halhal yang mereka tidak mengerti, dengan demikian anggoa jemaat akan menjadi kuat dalam iman dan dapat bertumbuh secara sehat dalam kehidupan rohani." 57

Melalui Pemahaman Alkitab jemaat didorong untuk menyelidiki Alkitab secara teratur dan sistematis. Marge Fuller mengatakan, "Melalu penyelidikan Alkitab, orang-orang Kristen bertekad untuk menyelidiki Firman Allah secara sistematis supaya mereka memperoleh hikmat dan kuasa Tuhan yang diperlukan untuk hidup secara Kristen." 58 Dalam kelompok PA seperti ini setiap anggota jemaat dapat menjalin hubungan baik antara satu dengan yang lainnya. Rob Jemson dan Jim Stevens mengatakan, "Dalam kelompok kecil memberi peluang untuk megembangkan jangkauan hubungan-hubungan yang lebih berarti dengan sesama anggota persekutuan." ${ }^{59}$ Ini berarti bahwa melalui kelompok kecil seperti ini merupakan tempat yang sangat ideal untuk meningkatkan kualitas iman dan pengenalan akan Yesus Kristus. Bob Jemson dan Jim Steven mengatakan, "Setiap gembala memiliki tanggung jawab besar dalam pemahaman Alkitab melalui kelompok kecil dan tanggung jawab seperti ini harus dilaksanakan secara terus menerus." 60

Dari pernyataan di atas, maka dapat ditarik suatu kesimpulan bahwa pemahaman Alkitab sungguh sangat penting bagi pendewasaan kehidupan rohani anggota jemaat, pemahaman Alkitab adalah kegiatan yang sangat penting dalam penggembalaan, pemahaman Alkitab adalah salah satu kegiatan yang menghimpun, menolong, mengaktifkan setiap peserta dan

\footnotetext{
${ }^{56}$ Navigator, Memimpin Kelompok Penelaan Alkitab. Jakarta: BPK Gunung Mulia, 1996,3

${ }^{57}$ Jermia Djadi, "Diktat Penggembalaan” (Ujung Pandang: STT Jaffray,1996),33

${ }^{58}$ Marge Fuller, Penyelidikan Alkitab secara induktif (Bandung: Kalam Hidup , 1978), 5

${ }^{59}$ Dinamika Pertumbuhan Gereja (Malang: Gandum Mas, 1996),198

${ }^{60}$ Ibid, 198
} 
sebagai gembala harus mampu menjadi motivator dari setiap kegiatan yang telah dibentuk sehingga menghasilkan kehidupan Kristen yang berbuah.

\section{Sebagai Pemberi Teladan}

Tugas pelayanan Rasul Petrus yang harus dilihat oleh para pemimpin gereja masa kini adalah memberi teladan. Ralp M.Riggs dalam bab III bahwa seseorang yang layak memimpin adalah orang yang mampu memberi teladan di dalam segala hal terhadap bawahan yang dipimpinnya. Karena itu, dalam menyandang tugas jabatan sebagai pemimpin harus menyatakan usaha yang sungguh-sungguh untuk memelihara sikap dan perbuatannya agar dapat menjadi berkat bagi orang yang dipimpinnya. Peter Wongso mengungkapkan hal yang sama bahwa di dalam hati jemaat pendeta memang seorang pemimpin. Oleh sebab itu, pendeta harus memelihara sikap dan perbuatan jemaatnya dengan sebaik-baiknya dan yang terpenting dirinya sendiri harus menjadi teladan bagi mereka. ${ }^{61}$ Anggota-anggota jemaat menuruti teladan para penatua, sedangkan para penatua sendiri menaati petunjuk-petunjuk Gembala Agung yang mempekerjakan gembalagembala yang ada di bawah-Nya sebagai milik kepercayaan-Nya. Gembala yang telah bertanggung jawab di hadapan Gembala Agung itu akan memperoleh mahkota kemuliaan pada hari kedatangan-Nya kelak.

Sebagaimana yang dijelaskan dalam Bab III dalam melayani Allah Rasul Petrus memberikan teladan kepada para penatua untuk tetap kokoh. Ketika menghadapi penganiayaan yang akan segera datang, keteladan iman ini dapat dilakukan oleh para pemimpin gereja pada masa kini, apalagi dalam menghadapi masalah atau kesukaran-kesukara hidup. Dalam hal ini, para pemimpin gereja harus menjadi misiator dan motivator serta harus mampu mempragakan iman yang teguh ketika menghadapi berbagai persoalan dalam pelayanan, seperti yang diungkapkan Robert Cowles, "adanya aktivitas manusia dalam kehidupan bersama sangat menuntut umat-Nya pada tujuan yang telah tertangkai di dalam rencana Allah."62 Seorang gembala harus menjaga sikap dan kelakuan dalam memberikan teladan, baik dalam hal kedusan, penguasaan diri, maupun di dalam keluarga.

\section{Teladan dalam Kekudusan}

Kamus umum Bahasa Indonesia mengartikan kekudusan sebagai "Kemurniaan, suci, bersih, dan mulia". ${ }^{63}$ Kekudusan dalam Perjanjian Lama didefinisikan dengan beberapa pengertian, ada yang mengartikan dengan mengaitkan Allah sendiri. Willyam Bierness mengatakan, "Kekudusan dalam Perjanjian Baru terutama dikaitkan dengan Allah sendiri. Dan baru

\footnotetext{
${ }^{61}$ Peter Wongso, Theologia Penggembalaan (Malang: SAAT, 1983),18

${ }^{62}$ Robert Cowles, Gembala Sidang (Bandung: Kalam Hidup, 1995),7

${ }^{63}$ Kamus Umum Besar Bahasa Indonesia.S.V."Kekudusan"
} 
kemudian (lewat perintah-Nya) dengan benda-benda dan tempat-tempat. Secara etimologi "Kudus" adalah terjemahan dari kata Ibrani "Qadosy" yang berarti "terpisah" (dikhususkan) atau "terpotong dari". ${ }^{64}$

Van Nittrik \&\& B.J.Bolan mengatakan, "Pengudusan adalah suatu realitas orang percaya kepada Kristus oleh karena Firman-Nya yang berisi rahmat itu, Allah membuat kita sebagai orang-orang yang dikuduskan. Namun kita sungguh-sungguh dikuduskan, disendirikan, dipisahkan sebagai jemaat yang secara khusus menjadi milik Kristus. I Korintus 1:2,30 menjelaskan, "Kekudusan diperoleh karena iman akan Kristus." Karena Allah, kita berada dalam Kristus yang sudah dibuat Allah menjadi kesucian kita, sehingga kita menjadi kudus.

Hidup kudus memang sangatlah sukar untuk dipraktikkan, namun yang perlu kita ketahui bahwa pengudusan adalah penyataan kuasa Allah kepada manusia, dan Allah mengampuni orang yang berdosa. Allah menguduskan manusia dengan memperhitungkan kekudusan Kristus pada orang percaya. Petrus berkata dalam pasal l:13, "Siapkanlah akal budimu" juga berarti kendalikan pikiranmu." 65 "Sebab itu, siapkanlah akal budimu, waspadalah dan letakkanlah harapanmu seluruhnya atas kasih karunia yang dikaruniakan kepadamu pada waktu penyataan Yesus Kristus. Hiduplah sebagai anak-anak yang taat dan jangan turuti hawa nafsu yang menguasai kamu pada waktu kebodohanmu, tetapi hendaklah kamu menjadi kudus di dalam hidupmu sama seperti Dia yang kudus, yang telah memanggil kamu, sebab ada tertulis Kuduslah kamu sebab Aku kudus" (I Petrus 1:13-16).

Gembala sebagai pemimpin harus menjadi teladan kepada jemaatnya dalam hal kekudusan. Ini berarti gembala sebagai pemimpin harus menghindari hal-hal yang dapat merusak citra diri sebagai gembala yang dipercayakan oleh Allah kepadanya. Karena apabila gembala tidak menjadi contoh dalam hal kekudusan itu, maka setiap anggota yang dipimpinnya tidak akan mengindahkan dan mendengar apa yang disampaikan itu. "Jadilah teladan dalam perkataan, dalam tingkah laku, dalam kasih, dalam kesetiaan, dan dalam kekudusan (I Timotius 4:12)." Gembala sebagai pemimpin dalam jemaat harus memiliki tekad untuk menjadi teladan hidup kudus dan mentaati Allah. Henry C.Thiessen mengatakan, "Dorongan yang paling kuat untuk hidup kudus bukanlah peraturan, melainkan teladan, khususnya seorang yang dekat dengan kita," ${ }^{66}$ sama seperti Petrus memberikan teladan bagi teman penatua untuk menjadi teladan bagi kawanan domba itu.

\footnotetext{
${ }^{64}$ Ensiklopedia Alkitab Masa Kini Jilid 2 (Jakarta: Yayasan Komunikasih Bina Kasih/OMF Jl. Letjen Suprapto 28 cempaka putih, 1992, S.V."Kudus"

${ }^{65}$ Warren W. Wiersbe, Pengharapan di Dalam Kristus (Bandung: Kalam Hidup,1982), 34

${ }^{66}$ Henry C Tissen. Teologi Sistematika (Malang: Gandum Mas,1995), 327 


\section{Teladan Dalam Penguasaan Diri}

Petrus menasihatkan kepada para perantau dan pendatang, untuk menjauhkan diri dari keinginan-keinginan daging yang berjuang melawan jiwa. Dan nasihat untuk tetap miliki cara hidup yang baik di tengah-tengah bangsa-bangsa bukan Yahudi, supaya apabila mereka memfitnah sebagai orang durjana, mereka dapat melihatnya dari perbuatan-perbuatanmu yang baik dan memuliakan Allah pada hari Tuhan melawat mereka. (I Petrus 2:11-12).

Gembala sebagai pemimpin jemaat harus menjadi teladan dalam hal penguasaan diri. Sebab tanpa penguasaan diri, maka ia akan sangat mudah terjerumus dalam jurang yang dapat menjatuhkan dia sebagai pemimpin dan tidak dapat memotivasi bagi jemaatnya. Dalam bahsa Yunani kata menguasai diri adalah $\zeta \gamma \kappa \rho \alpha \tau \eta \zeta$ ( egkrates). ${ }^{67}$ Fritz Reinecker memberi arti kata egkrates adalah kesadaran, penguasaan yang sempurna, yang menahan semua dorongan nafsu, dan taat kepada Allah. ${ }^{68}$

Jadi, penguasaan diri merupakan suatu kekuatan dalam yang dapat memampukan secara sempurna untuk menghindari segala nafsu duniawi agar tetap berjalan sesuai dengan rencana Tuhan. Oleh sebab itu, gembala sebagai pemimpin harus mampu untuk menguasai dirinya supaya ia dapat menjadi teladan bagi anggota jemaat yang dipimpinnya.

\section{Teladan Dalam Keluarga}

Betapa pentingnya keluarga gembala sebagai pemimpin untuk menjadi teladan dalam jemaat, jika ada di antara mereka (Suami) yang tidak taat kepada Firman, mereka juga tanpa perkataan dimenangkan oleh kelakuan istrinya, jika mereka melihat bagaimana kemurnian dan salehnya hidup istri mereka itu (I Petrus 3:1-2). Kenyataannya bahwa ada gembala yang mampu memenangkan banyak jiwa, berkhotbah dengan berapi-api dan bahkan dapat mengembangkan gereja dengan baik, tetapi di dalam keluarganya (rumah tangganya) tidak ada keharmonisan. Anak-anak hidup jauh dari Tuhan, istri kurang menghargai suami dan suami kurang memperhatikan istri dan anak. Clyde M. Narramore Mengatakan; "Di dalam keluarga yang sehat, baik orang tua maupun anak-anak sama-sama membina saling rasa menghargai, sang suami memperlakukan istri dengan baik dan dengan kasih, dengan demikian ia memberi teladan bagi seluruh keluarganya. ${ }^{69}$ Sejalan dengan Ralph M. Riggs Mengatakan, "Seorang

\footnotetext{
${ }^{67}$ Newman Jr Barclay M. Kamus Yunani Indonesia (Jakarta BPK Gunung Mulia, 1993),S.V. "Egrates"

${ }^{68}$ Firtz Reinecker, A Linguistic Key to the Greek New Testament Vol 2 (Mechigan: Grand Rapids Zondervan Corporation), n.d.

${ }^{69}$ Clyde M. Narramore, Liku-Liku Problem Rumah Tangga (Bandung : Kalam hidup,n.d),13
} 
gembala harus menjadikan rumah tangganya sebagai contoh bagi anggota jemaatnya. Ini merupakan cara yang amat indah untuk memberitakan Injil

${ }^{70}$ Peranan seorang istri dan anak gembala merupakan salah satu faktor yang amat penting dalam menunjang kewibawaan seorang gembala dalam pelayanan jemaat. Istri sebagai penopang suami; pertama, harus mengerti tugas dan kedudukan suaminya sebagai gembala jemaat. Gembala jemaat menghadapi bermacam-macam tuntutan untuk dapat menjadi teladan bagi jemaat. Kedua, harus ikut serta dalam panggilan melayani Tuhan, menjadi teman sekerja yang dewasa, aktif dalam kegiatan gereja, memperhatikan anggota jemaat dan keadaan gereja, mendoakan suami, membantu menyiapkan segala sesuatu yang diperlukan suami dalam pelayannya. Ketiga, menghibur suami, memberi semangat. Anak-anak yang tahu menghormati Tuhan dan orang tuanya dapat menjadi teladan kepada anggota jemaat yang merupakan faktor penunjang bagi gembala. Tetapi apabila anak-anaknya tidak menghormati Tuhan akan mendatangkan kritikan dari anggota jemaat dan bukan untuk menjadi teladan, tetapi menjadi batu sandungan bagi anggota jemaat dan orang-orang yang di sekitarnya.

Oleh sebab itu, seorang gembala harus mampu untuk membina keluarganya terlebih dahulu, sehingga melalui keluarganya dapat menjadi teladan bagi jemaat dan masyarakat yang ada di sekitar di mana ia tinggal.

\section{Kesimpulan}

Berdasarkan semua uraian tentang peranan gembala sebagai pemimpin dalam perspektif I Petrus 5:1-4, maka dapat ditarik beberpa kesimpulan:

Pertama, konsep I Petrus 5:1-4 Tentang peranan gembala sebagai pemimpin bahwa seorang gembala harus mengerti peranannya sebagai pemimpin, yaitu: (1). Pemimpin yang memberi nasihat (I Petrus 5:1), seorang gembala sebagai pemimpin yang meberi nasihat harus mampu mengajarkan hal-hal yang baik dan menganjurkan sesuatu yang berguna bagi bawahannya atau orang-orang yang dipimpinnya, (2). Pemimpin yang bertanggung jawab (I Petrus 5:2a), seorang pemimpin sejati adalah orang yang penuh dengan rasa tanggung jawab, pemimpin yang mau memikul, menerima dan mengambil tanggung jawab dengan penuh kesadaran untuk tugas dan orang yang telah dipercayakan Tuhan kepadanya dan bukan orang yang menghindar dari tanggung jawab, (3). Pemimpin yang sukarela (I Petrus 5:2), sebagai pemimpin harus mampu menerima dan menlayani bawahannya dengan hati yang terbuka, senang dan bukan bekerja karena paksaan tetapi dengan kemauannya sendiri, (4). Pemimpin yang memberi teladan (I Petrus 5:3), sebagai pemimpin ada tuntutan sikap teladan dalam

\footnotetext{
${ }^{70}$ Ralph M .Riggs, Gembala Sidang Yang Berhasil (Malang: Gandum Mas,1996), 38
} 
seluruh aspek kehidupannya baik kehidupan rohani, hubungan dengan orang lain, dalam pekerjaan, dan lewat sikap tegas.

Kedua, adapun relevansi gembala sebagai pemimpin bagi penggembalaan masa kini yaitu: (1). Sebagai konselor atau pembimbing, harus peka terhadap orang - orang yang dibimbingnya dan selalu siap menerima keluhan dari bimbingannya tanpa ada motivasi lain, (2). Sebagai gembala yang bertanggung jawab, seorang pencuri hanya datang untuk merampok dan membinasakan, tetapi gembala yang mengasihi pasti melindungi atas domba-dombanya dari serangan yang akan datang dan bertanggung jawab atas domba-domba yang digembalakannya, (3). Menjaga dan melindungi jemaat, sebagai gembala harus selalu mengadakan tindakan pencegahan untuk mengantisipasi hal-hal yang tidak diinginkan, mengadakan perawatan bagi jemaatnya, dan mengadakan perkunjungan bagi domba-domba yang digembalakan atau jemaat, (4). Dalam mengajar, seorang gembala atau pemimpin adalah guru yang akan terus menerus mengajar dan memberikan pengajaran firman Tuhan kepada anggota jemaatnya, dalam berkhotbah, adalah salah satu cara yang diberikan oleh Allah untuk menyampaikan firman-Nya kepada umat-Nya, pemahaman Alkitab (PA), adalah sangat penting bagi pendewasaan kehidupan rohani anggota jemaat, (5). Sebagai pemberi teladan, seorang pemimpin harus menjaga sikap dan perbuatan jemaatnya dengan sebaik-baiknya dan yang terpenting dirinya sendiri harus menjadi teladan bagi mereka yang dipimpinnya dan sebagai seorang gembala harus bisa memberikan teladan bagi orang yang dipimpinnya baik teladan dalam kekudusan, teladan dalam penguasaan diri, dan teladan dalam keluarga. 


\section{DAFTAR PUSTAKA}

Andrew Murray, Membina Iman (Bandung: Kalam Hidup,1995)

Clyde M. Narramore, Liku-Liku Problem Rumah Tangga (Bandung : Kalam hidup,n.d)

Diane Tracy, 10 Langkah Meraih Kekuasaan (Jakarta: Pustaka Tangga,1999)

Dinamika Pertumbuhan Gereja (Malang: Gandum Mas, 1996)

Engstrom Dayton, Seni Manajemen Bagi Kepemimpinan Kriste. (Bandung: Kalam Hidup,1998)

Ensiklopedia Alkitab Masa Kini Jilid 2 (Jakarta: Yayasan Komunikasih Bina Kasih/OMF Jl. Letjen Suprapto 28 cempaka putih, 1992, S.V."Kudus"

Firtz Reinecker, A Linguistic Key to the Greek New Testament Vol 2 (Mechigan: Grand Rapids Zondervan Corporation), n.d.

Frederic K. C Price, Saran Saran Praktis untuk Pelayananyang berhasil (Jakarta: Yayasan Pekabaran Injil Immanuel, 1997)

Henry C Tissen. Teologi Sistematika (Malang: Gandum Mas,1995)

J. Oswald Sanders, Kepemimpinan Rohani (Bandung: Kalam Hidup,1999)

Jermia Djadi, "Diktat Penggembalaan" (Ujung Pandang: STT Jaffray,1996)

Jermia Djadi "Teologi Pastoral" (Makassar: Sekolah Tinggi Theologia

Jaffray, 2005)

Kamus Besar Bahasa Indonesia, S.V. "Teladan"

Kenneth O.Gandel, Membina Pemimpin Pendidikan Kristen (Malang: Gandum Mas, 2001)

Leroy Eims, 12 Ciri Kepemimpinan Yang Efektif (Bandung: Kalam Hidup,1999)

Marge Fuller, Penyelidikan Alkitab secara induktif (Bandung: Kalam Hidup , 1978)

Myron Rush, Pemimpin Baru (Jakarta: Yayasan Pekabaran Injil/Immanuel, 1991)

N.Mimery, Rahasia Tentang Penggembalaan Jemaat (n.p: Mimery Press,n.d)

Navigator, Memimpin Kelompok Penelaan Alkitab . Jakarta: BPK Gunung Mulia, 1996

Newman Jr Barclay M. Kamus Yunani Indonesia (Jakarta BPK Gunung Mulia, 1993),S.V. "Egrates"

P.Tuhumury. "Pedoman Pimbinaan Pendidikan Kristen" (Makassar: STT Jaffray, 2003)

Pendeta dan Tugas Pendidikan Dalam Jemaat (Pengarang Sebagai Entri Utama, STT Jaffray, n.d)

Peter Anggu,. Etika Penggembalaan (Makassar: STT Jaffray. 2003)

Peter Wongso, Theologia Penggembalaan (Malang: SAAT, 1983)

Ralp M. Riggs Gembala Sidang Yang Berhasil (Malang: Yayasan penerbit Gandum mas,1996)

Ralph M .Riggs, Gembala Sidang Yang Berhasil (Malang: Gandum Mas,1996) 
Robert Cowles, Gembala Sidang (Bandung: Kalam Hidup, 1995)

Ronald W.Liegh, Melanyani Dengan Efektif (Jakarta: BPK Gunung Mulia, n.d)

Ruth F Selan, Pembina Warga Jemaat (Bandung: Kalam Hidup,1994)

Ruth F. Selan, Bimbingan Praktis (Ujung Pandang: STT Jaffray, 1993)

Sondang P. Siagian, Teori dan Praktek Kepemimpinan (Jakarta: RINEKA CIPTA,1991)

Tafsiran Alkitab Masa kini 3 Matius-Wahyu (Jakarta: Yayasan Komunikasih Bina Kasih/OMF,2003)

Ulrich Beyer Tafsiran Surat 1 dan 2 Petrus dan Surat Yudas (Jakarta: BPK Gunung Mulia,1972)

Ulrich Beyer Tafsiran Surat 1 dan 2 Petrus dan Surat Yudas (Jakarta: BPK Gunung Mulia,1972)

Warren W. Wiersbe, Pengharapan di Dalam Kristus (Bandung: Kalam Hidup,1982)

Warren W.Wiersbe dan Howard F. Sugden, Memimpin Gereja Secara Mantap.(Bandung: LLB, 1994)

Warren W.Wiersbe, Prioritas Seorang Pendeta (Malang: Penerbit Gandum Mas,1982)

Weslley Brill, Tafsiran Injil Yohanes (Bandung: Kalam Hidup, 1976)

Willyam Barcley, Pemahaman Alkitab Setiap Hari (Jakarta : BPK Gunung Mulia, 2000)

Yakob Tomatala, Kepemimpinan yang Dinamis (Jakarta : YT. Leadership Foundation,1997)

Yakob Tomatala, Menggembalakan Seperti Yesus Kristus (Jakarta: Yakob Tomata Leadership Foundation,2005)

Yakub B. Susabda, Pastoral Konseling. (Malang: Penerbit Gandum Mas, 1985) 